\title{
Mutrikuko olatu zentralaren azterketa eta potentzia maximoko puntuaren jarraipena
}

\author{
(A study of Mutriku Wave Power Plant and Maximum \\ Power Point Tracking-based Control)
}

\author{
Jon Lekube Garagarza*, Aitor J. Garrido Hernandez, \\ Izaskun Garrido Hernandez
}

Sistemen Ingeniaritza eta Automatika saila UPV/EHU

* jon.lecube@ehu.eus

DOI: $10.1387 /$ ekaia.16402

Jasoa: 2016-05-26

Onartua: 2016-09-27

Laburpena: Susperraldian dauden energia iturri berriztagarri berriak berebiziko garrantzia izatera iritsi dira gaur egungo gizartean. Petrolioarekiko menpekotasuna eta berotegi efektua direla medio, energia lortzeko bide berriak miatu beharra nabarmendu da. Ozeanoek eta itsasoek energia kantite handia pilatzen dute bere baitan. Hala ere, gizakia oraindik ez da gai izan energia honetaz egokiro baliatzeko. Ur-zutabe oszilatzailean oinarritutako metodoa da gaur egun itsasotik energia ateratzeko sistema guztien artetik gehien ikertuenetako bat. Alabaina, lorturiko efizientzia baxuek zaildu egiten dute teknologia honen erabilera. Gaur egungo kontrol-metodo berriek, aldiz, efizientzia hau hobetzea ahalbidetzen dute. Metodo hauen artean badago potentzia maximoko puntuaren jarraipena, batez ere energia eolikoan asko erabilia.

Hitz-gakoak: olatu-energia, ur-zutabe oszilatzailea (OWC), potentzia maximoko puntuaren jarraipena (MPPT).

\begin{abstract}
New emerging renewable energy sources are reaching a vital importance in the actual society. Novel ways of energy harnessing must be explored to overcome fuel dependency and the global warming. There is a huge amount of energy to be obtained from oceans and seas. However, the human being has not been able to harness this energy properly. Oscillating Water Column-based (OWC) method is at present one of the most studied techniques among the ocean energy systems. Nonetheless, low efficiencies in energy conversion hinder the success of this technology. The recent control methods allow to improve this efficiency. Among these methods the Maximum Power Point Tracking (MPPT) strategy can be found, which is extensively used in wind energy.
\end{abstract}

Keywords: wave energy, Oscillating Water Column (OWC), Maximum Power Point Tracking (MPPT). 


\section{SARRERA}

Azken mende honetan, nabarmen igo da gure gizartearen energia-kontsumoa. Industriaren garapenak eta bizi-kalitatearen hobekuntzak energiamendekotasuna ere areagotu du bere horretan. Arazo honi aurre egin ahal izateko, hainbat metodo garatu dira energia-iturri desberdinak erabiliz energia hau eraldatzeko. Hala ere, erregai fosiletan edota fisio nuklearrean oinarritzen dira haietako asko, tamalez gaur egun gehien erabilienak. Erregai fosilak etorkizun hurbilean agortuko dira ziur aski, baina gainera, fisio nuklearreko zentralen segurtasuna zalantzan jarri dute azken hiru hamarkadetan Chernobyl eta Fukushiman gertatutako istripuek. Gainera, ingurumena babestearen aldeko kontzientzia nabarmen hasi da, bai gizartean baina baita agintarien artean ere. Honen adibide argia dugu 2015eko azaroan eta abenduan Parisen ospatutako Nazio Batuen Klima Aldaketaren Konferentzia (COP21), berotegi-efektua $2{ }^{\circ} \mathrm{C}$-ra mugatu duena [1].

Efizientzia energetikoak eta energia berriztagarriek ezinbesteko garrantzia hartu dute $\mathrm{CO}_{2}$-igorpena eta erregaiekiko mendekotasuna murrizteko. Nahiko heldutasun erdietsi dute batez ere energia hidraulikoak baina baita energia eolikoak eta eguzki-energiak ere. Hala ere, energia-iturri berriztagarri berriak ezinbestekoak izango dira energia-kontsumoari aurre egiteko. Iturri hauen artean daude biomasa, energia geotermikoa edota itsas energia. Hauetako bakoitzean hainbat teknologia garatu dira, baina edonola, oraindik ez da lortu desiratutako efizientziaz energia eraldaketa gauzatzea. Hau dela eta, ikerkuntza-egitasmo anitzak [2-4] garatu dira teknologia hauen efizientzia hobetzeko asmoz; horrela, mundu osoan zehar hedatu da gai honekiko interesa.

Artikulu honetan landutako gaiari jarraiki, esan beharra dago gure planetaren \% 70a, ozeanoek eta itsasoek osatzen dutela batez beste. Hau dela eta, bertatik lor daitekeen energia kantitate handiak agerian gelditzen dira. Itsasoko ur-azalaren mugimendu etengabeek energia zinetikoa garraiatzen dute, eta hau, energia-bihurgailu egokien bidez energia elektriko bilaka daiteke. Jarraian ikus daitekeen bezala, bihurgailu hauek talde desberdinetan sailkatu daitezke erabili nahi den energia-iturriaren arabera:

- Olatu-energia: olatuen gora eta beherako mugimendua baliatzen dute energia eraldatzeko. Olatuek energia kantitate handiak pilatzeaz gain, baldintza egokiak aurreikusteko erraztasuna ere eskaintzen dute.

- Marea-energia: mareek sortutako itsasgora eta itsasbeheraren arteko garaiera-desberdintasuna erabiltzen dute metatuko energia potentziala eraldatzeko. Metodo hau garatzeko eragozpenak egon dira, azpiegitura handia eta kokapen egokia behar dituelako eta ingurumenarazoak eragiten dituelako. 
- Korronte-energia: Ozeanoetan sortzen diren ur-masen mugimenduetatik eratorritako energia da. Korronte hauek iraunkorrak dira, eta beraz, aurresangarriak.

- Energia mareotermikoa: sakoneko ur hotzaren eta ur-azaleko ur epelaren arteko desberdintasunaz baliatzen dira sorgailu termiko bat mugitzeko. Tenperatura-aldaketa handiko lekuen eskasiak mugatzen du metodo honen erabilpena.

- Energia osmotikoa: Itsasoko eta ibaietako uren gatz-kontzentrazio maila desberdinen ondorioz erabilitako energia da.

Goian azaldutako arrazoi horiengatik guztiengatik, olatu-energia eta korronte-energia dira gaur egun gehien ikertutako itsas energi iturriak. Artikulu honetan lehenengo multzoa sakonago aztertuko da.

\section{OLATU-ENERGIA}

Olatuen energia erabiltzeko zenbait teknologia garatu dira azken urteetan. Teknologia hauen artean badaude ur-zutabe oszilatzailea (LIMPET [5]), Arkimedes efektuan oinarritutakoak (AWS ocean [6]), bakarkako edo taldekako egitura flotatzaileak (AquaBuOY [7], Pelamis [8]) edota gaineztatzean oinarritutakoak eta talka-sistemak (Wave Dragon [9]). Hala ere, oraindik ezin dugu jakin hauetako zeinek emango dituen emaitzarik onenak.

2050 urterako aurreikusita dago mundu osoan itsasotik $337 \mathrm{GW}$ erabiliko direla, eta horretarako beharrezkoa den teknologia ordurako garatua egotea espero da [9]. Olatu-energiari dagokionez, urtero $16 \mathrm{PWh}$ energia sortzeko aukera izango da. Gutxi gorabehera 2040rako espero den kontsumoaren \% 50a lortuko litzateke olatu-energiari esker. Ikusmira Euskal Herrian jarrita, 2020rako 60 MW-ko jomuga ezarri zuen Eusko Jaurlaritzak 2011an [10]. Helburu hauek lortzeko beharrezkoa da teknologia honen errendimendua hobetzea beronen errentagarritasuna bermatzeko; eta horretan ezinbestekoak dira Mutrikuko NEREIDA MOWC olatu zentrala eta $\mathrm{Ar}-$ mintzako BIMEP proiektua [11], garapen hau errazteko.

\subsection{Mutrikuko olatu zentrala}

2011 ko uztailean jarri zen abian ur-zutabe oszilatzailea (ingelesez, Oscillating Water Column) deritzon printzipioan oinarritutako olatuen energia erabili ahal izateko lehendabiziko zentrala Euskal Herrian. Zentral hau Mutrikun kokatuta dago eta NEREIDA MOWC izena du [11,12]. 1. irudian ikus daitezkeen moduko $18.5 \mathrm{~kW}$-ko 16 sorgailuz osatua dago, eta beraz, guztira $296 \mathrm{~kW}$-ko potentzia elektrikoa sortzeko gai da. Hala ere, itsasoaren baldintzen arabera sortzen du aldiune bakoitzean potentzia. Hots, itsaso barea dagoenean eta olatu askoko itsasaldia dagoenean ez dira beti potentzia berdinak sortzen. 
Jon Lekube Garagarza, Aitor J. Garrido Hernandez, Izaskun Garrido Hernandez.

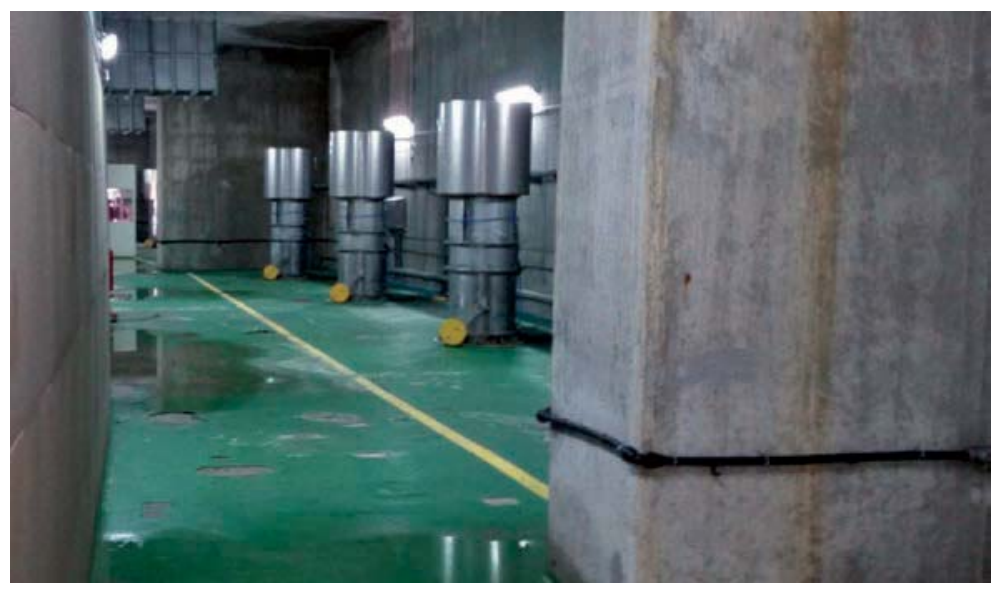

1. irudia. Mutrikuko NEREIDA MOWC olatu zentrala.

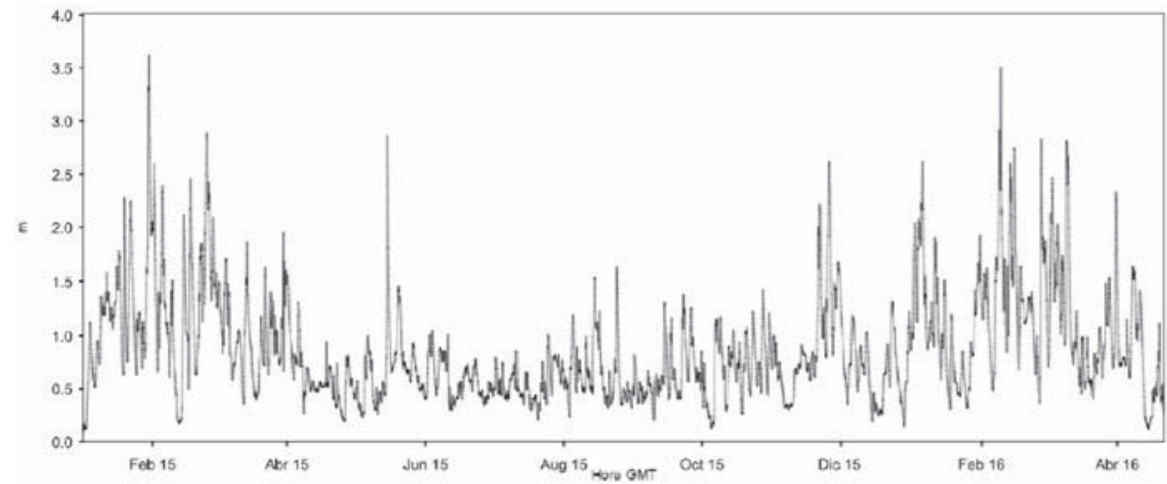

2. irudia. Olatuen aldiuneko altuera (3171032 SIMAR puntua).

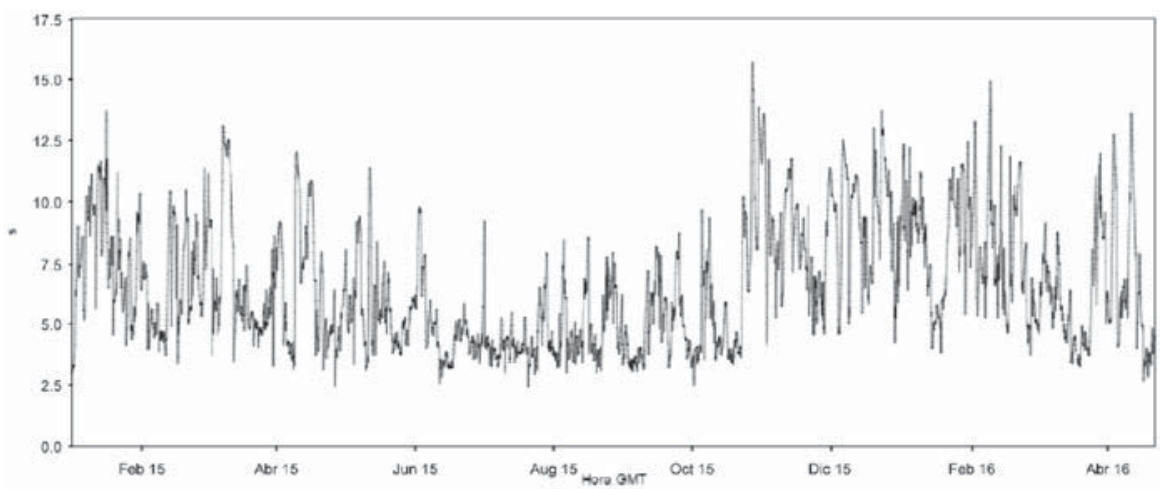

3. irudia. Olatuen aldiuneko periodoa (3171032 SIMAR puntua). 
Hau dela eta, beharrezkoa da kokapen horri dagozkion itsasaldien datuak ezagutzea azterketa sakonago bat burutu ahal izateko.. Gaur egun dauden neurgailuak itsaso sakonean kokatzen dira. Beraz, ezinezkoa da zentralaren inguruan jasotzen diren olatuen mailak zehazki neurtzea. Hala ere, hurbilen kokatuta dagoen neurgailua (3171032 SIMAR puntua) 1.25 itsas milia iparralderantz dago [13], eta beraz, beronek emandako datuak baliogarritzat har daitezke.

Neurgailu honek emandako datuen arabera, olatu zentrala kokatzen den kostaren inguruan 1 metroko altuera eta 10 segundoko periodoa duten olatuak gertatzen dira urtean zehar batez beste. Hala ere, balio hauek aldaketak jasan ditzakete urte-sasoiaren arabera. 2. eta 3. Irudietan ikus daitezke hurrenez hurren olatuen altueren eta periodoen aldiuneko balioak, urte oso batean zehar gertatu direnak.

\subsection{Ur-zutabe oszilatzailea}

Ur-zutabe oszilatzailea (OWC) ganbera batean dagoen airearen presio-aldaketetan oinarritzen da. Presio-aldaketa hau olatuen sarrera-irteerek sortzen dute. Horretarako, teknika honetan oinarritzen diren sistemen elementu garrantzitsu bat izaten da harrapaketa-ganbera, ur maila azpitik irekigune bat izaten duena. Irekigune honetatik sartzen dira olatuak ganberara, eta bertan dagoen airea konprimitzen dute [14]. Bestalde, ganberaren goiko aldean hodi bat dago, eta bertan turbina kokatzen da. Olatuak ganberara sartzean eragindako presio-igoeraren ondorioz, bertako airea hoditik igarotzen da eta turbina mugiarazten du. Era berean, olatuaren irteerak utzitako hutsuneak presio-jaitsiera bat eragiten du ganberaren barruan. Ondorioz, desplazatu egin den aire-bolumena turbina dagoen hoditik zehar berriro igarotzen da ganberara, eta olatuak utzitako hutsunea betetzen du.

Hainbat teoria garatu dira olatuen dinamika aztertzeko: Airy, Stokes, Cnoidal eta olatu bakartia. Airyrena [15-16] litzateke deskribapen goiztiar eta bakunena. Teoria honek zehaztasun nahikoa eskaintzen du ingeniaritzako hainbat arazo ebatzi ahal izateko.

Teoria hau garatuz, frogatzen da hoditik igarotzen den airearen abiadura honako ekuazioarekin kalkula daitekeela [17],

$$
v_{t}(t)=\frac{8 a w c}{\pi D^{2}} \cdot \sin \frac{\pi l}{c T} \cos \frac{2 \pi}{T} t,
$$

non, $a$ olatuaren anplitudea den, $T$ olatuaren periodoa eta $c$ olatuaren abiadura. Era berean, baditugu $w$ harrapaketa-ganberaren zabalera, $l$ luzera eta $D$ hodiaren diametroa. Beraz, olatuaren ezaugarriek ez ezik, ganbararen ezaugarriek ere eragina dute airearen abiaduran.

Ekuazio hau erabilita edozein olaturen altuera eta periodorentzat harrapaketa-ganbera barneko airearen abiadura desberdinak kalkula daitezke. 
Jon Lekube Garagarza, Aitor J. Garrido Hernandez, Izaskun Garrido Hernandez

1. Taulan laburbiltzen dira 0.25 eta 2 metro bitarteko olatu-altuerek eta 1 eta 12 segundo bitarteko periodoek sortzen dituzten airearen abiaduren balioak. Era berean, 4. irudiak modu grafikoan biltzen ditu balio hauek.

1. taula. Olatuaren altuera eta periodo desberdinek sortzen dituzten harrapaketaganbera barneko airearen abiadurak $(\mathrm{m} / \mathrm{s})$.

\begin{tabular}{|c|c|c|c|c|c|c|c|c|c|}
\hline & \multicolumn{8}{|c|}{ Olatuaren altuera (m) } \\
\hline & & 0.25 & 0.50 & 0.75 & 1.00 & 1.25 & 1.50 & 1.75 & 2 \\
\hline \multirow{12}{*}{ 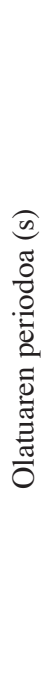 } & 1 & 33.377 & 66.755 & 100.13 & 133.51 & 166.89 & 200.26 & 233.64 & 267.02 \\
\hline & 2 & 29.305 & 58.610 & 87.915 & 117.22 & 146.52 & 175.83 & 205.13 & 234.44 \\
\hline & 3 & 21.384 & 42.768 & 64.152 & 85.536 & 106.92 & 128.30 & 149.69 & 171.07 \\
\hline & 4 & 16.540 & 33.081 & 49.621 & 66.162 & 82.702 & 99.243 & 115.78 & 132.32 \\
\hline & 5 & 13.421 & 26.842 & 40.263 & 53.684 & 67.104 & 80.525 & 93.946 & 107.37 \\
\hline & 6 & 11.270 & 22.540 & 33.810 & 45.080 & 56.350 & 67.620 & 78.890 & 90.160 \\
\hline & 7 & 9.7045 & 19.409 & 29.114 & 38.818 & 48.523 & 58.227 & 67.932 & 77.636 \\
\hline & 8 & 8.5168 & 17.034 & 25.551 & 34.067 & 42.584 & 51.101 & 59.618 & 68.135 \\
\hline & 9 & 7.5860 & 15.172 & 22.758 & 30.344 & 37.930 & 45.516 & 53.102 & 60.688 \\
\hline & 10 & 6.8374 & 13.675 & 20.512 & 27.349 & 34.187 & 41.024 & 47.862 & 54.699 \\
\hline & 11 & 6.2225 & 12.445 & 18.668 & 24.890 & 31.113 & 37.335 & 43.558 & 49.780 \\
\hline & 12 & 5.7087 & 11.417 & 17.126 & 22.835 & 28.543 & 34.252 & 39.961 & 45.669 \\
\hline
\end{tabular}

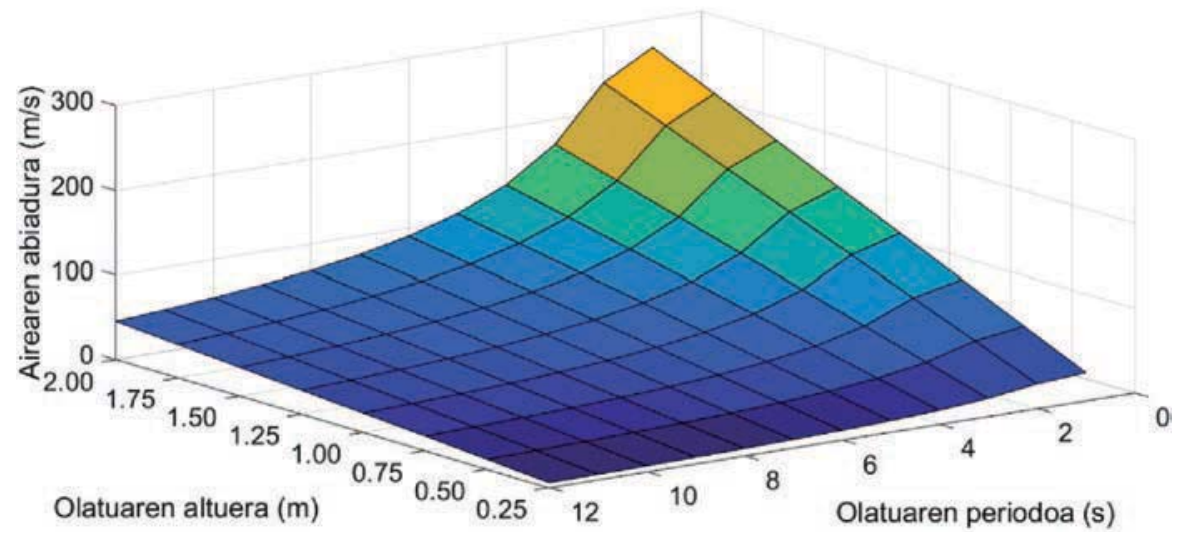

4. irudia. Harrapaketa-ganbera barneko airearen abiadurak olatuaren altuera eta periodo desberdinetarako. 
2. eta 3. irudietan ikus daiteke gorriz mugatutako eremuaren barnean daudela Mutrikuko kostaldean jasotzen diren olatuek batez beste sorturiko aire fluxuaren abiadurak.

Ikus daitekeenez, $20 \mathrm{~m} / \mathrm{s}$ eta $40 \mathrm{~m} / \mathrm{s}$ bitartean jasotzen dira harrapaketaganbera barneko airearen abiaduraren balio deigarrienak.

Lehenago esan bezala, turbinatik igarotzen den aireak bi noranzko ditu olatuak sartzean eta irtetean duen energia erabili nahi delako. Hala ere, sorgailuaren ardatzean bi noranzkoko mugimendua lortu beharrak potentziaelektronika konplexuago eta garestiago bat erabiltzera behartuko gintuzke. Hau ekiditeko konponbideetako bat Wells motako turbinak dira. Turbinaren itxura simetrikoa izaki, bi noranzkoko airea eduki arren, noranzko berean gertatzen da beti turbinaren biraketa. 5. irudian ikus daiteke Mutrikun muntatuta dauden Wells turbinetako bat.

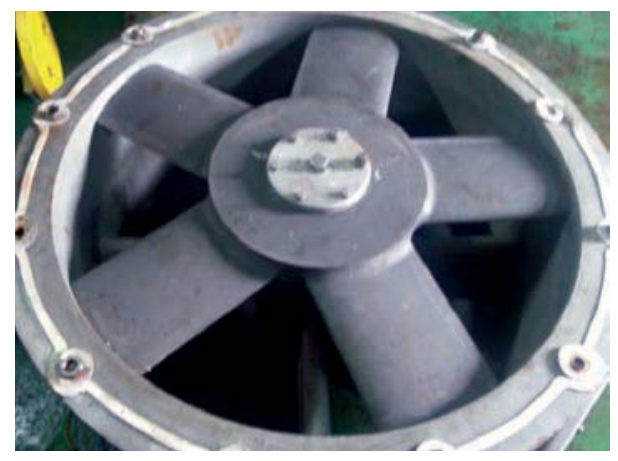

5. irudia. Wells turbina.

$C_{a}$ potentzia-koefizientea eta $C_{t}$ momentu-koefizientea dira Wells turbinaren ezaugarri garrantzitsuenak. Momentu-koefizienteak mugatu egingo du turbinaren errendimendua.

6. irudiko balio hauek enpirikoak dira, baina badago beraiekiko hurbilketa matematiko bat egitea.
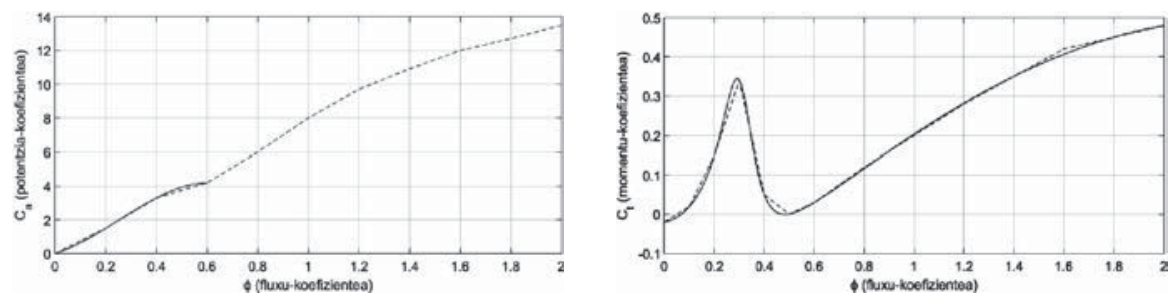

6. irudia. Potentzia-koefizientea (ezkerrean) eta momentu-koefizientea (eskuinean). Balio enpirikoa (lerro etena) eta hurbilketa matematikoa (lerro jarraia). 
$\Phi$ fluxu-koefizientea erabiltzen da koefiziente hauen balioa lortzeko sarrera gisa. Koefiziente honek bere gain hartzen ditu besteak beste harrapaketa-ganberako aire-fluxuaren abiadura eta turbinaren biraketa abiadura:

$$
\phi=\frac{v_{t}}{r \cdot \omega_{t}} .
$$

Harrapaketa-ganberan dagoen airearen presio-aldaketa sarrerako olatuaren araberakoa izateaz gain, turbinaren biraketa-abiadurak ere badu zerikusia. Izan ere, turbinaren biraketa zenbat eta azkarragoa izan, mugiaraziko den aire-bolumena handiagoa da, eta beraz, airearen presio-aldaketa ere handiagoa izango da ganbera barnean. Wells turbinen kasuan, jarraian deskribatutako ekuazioarekin kalkula daitezke harrapaketa-ganberan gertatzen diren presio-aldaketak:

$$
d P=C_{a} \frac{\rho b l_{1} n}{2} \frac{1}{a_{1}}\left(v_{t}^{2}+\left(r \cdot \omega_{t}\right)^{2}\right),
$$

non, $C_{a}$ aipatutako potentzia-koefizientea den, $\varrho$ airearen dentsitatea, $b$ turbinaren palaren zabalera, $l_{l}$ palaren luzera, $n$ pala kopurua, $r$ turbinaren erradioa eta $a_{l}$ turbinak barreiatutako azalera.

Turbina eta sorgailua ardatz berean kokatzen dira, lehenbizikoak emandako indar-momentua bigarrenera transmititzen delarik. Presio-aldaketaren kasuan bezala, indar-momentua ere sarrerako olatuak sortutako airearen abiaduraz gain, turbinaren biraketa-abiaduraren araberakoa ere izango da:

$$
T_{t}=C_{t} \frac{\rho b l_{1} n}{2} r\left(v_{t}^{2}+\left(r \cdot \omega_{t}\right)^{2}\right) .
$$

Kasu honetan potentzia-koefizientearen ordez momentu-koefizientea erabiltzen da. Koefiziente honen itxura dela eta, indar-momentuari dagokionez hiru funtzionamendu-eremu desberdin bereiz daitezke 7. irudian ikus daitekeen bezala:

1. Galera- edo stalling-eremua deritzona turbinaren abiadura txikietan gertatzen da, gutxi gorabehera $250 \mathrm{rad} / \mathrm{s}$ azpitik sarrerako olatuaren arabera. Bertan, balio txikiko erorketa bat nabari da indar-momentuan. Erorketa hau momentu-koefizientearen itxuragatik gertatzen da - hots, turbinaren ezaugarri bat da - eta fluxu-koefizientearen balioak $\Phi=0.3$ balioa gainditzen duenean gertatzen da.

2. Potentzia optimoko eremuan turbinak ematen duen indar-momentua maximoa da, eta beraz, sorgailuari emandako potentzia meka- 
nikoa ere maximoa izango da. Eremu honetan lortzen dira sistemak atzeman dezakeen efizientziarik altuenak.

3. Efizientzia-erorketa deritzon eremuan turbinak emandako indar-momentua gain behera etortzen da, turbinaren abiadura handitu arren.

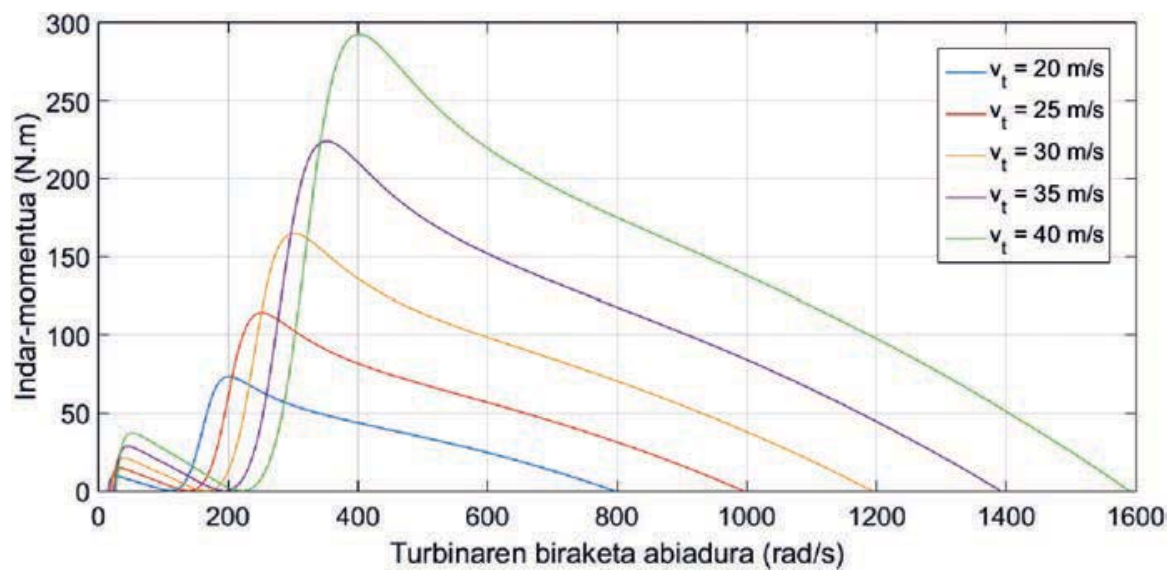

7. irudia. Indar-momentua Wells turbinetan harrapaketa-ganberako airearen abiadura, $v_{t}$, desberdinetarako.

Sorgailuak turbinak emandako potentzia mekanikoa potentzia elektrikora eraldatzen du. Potentzia mekanikoa indar-momentuaren eta turbinaren biraketa-abiaduraren arteko erlazioren bidez kalkula daiteke. Ondorioz, 8. irudian ikus daitezke aztertutako sistemaren kasurako lortutako potentzia mekanikoak.

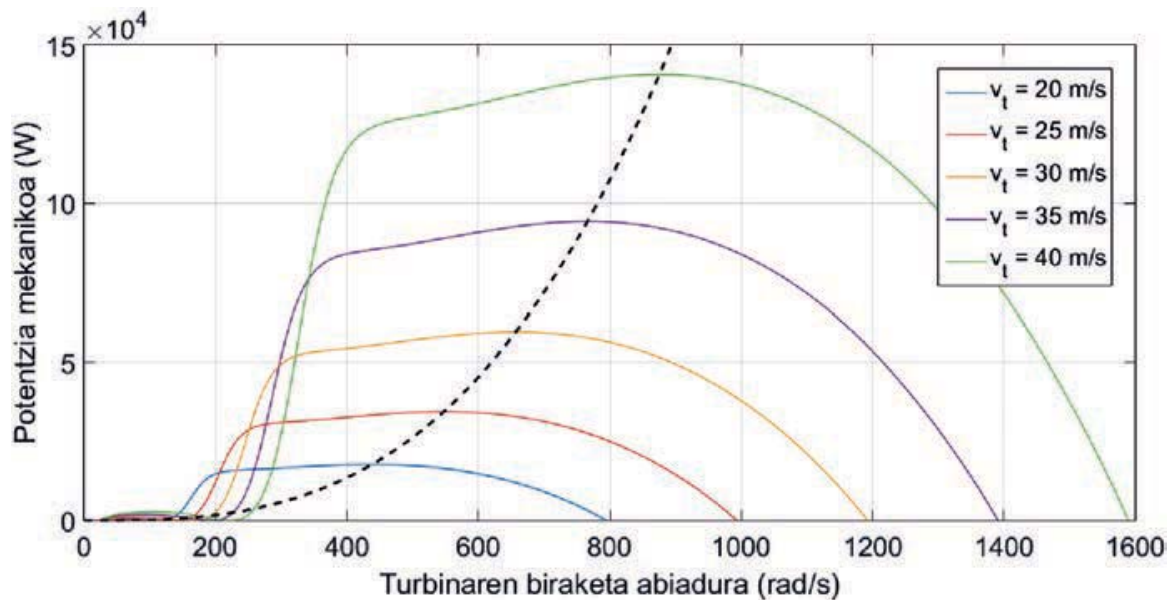

8. irudia. Potentzia mekanikoa Wells turbinetan harrapaketa-ganberako airearen abiadura, $v_{t}$, desberdinetarako. 
Sistemaren efizientzia hobetzea helburu hartuta, bigarren eremuan, hots potentzia maximoko eremuan lan egitea litzateke hoberena. Eremu hau lerro etenez adierazi da 8. irudian eta ondoren aztertuko den bezala berau jarraitzea izango da kontrol-sistemaren helburua.

\section{KONTROL SISTEMA}

8. irudian ikus daitekeen bezala, turbinak sorgailuari emandako potentzia mekanikoa harrapaketa-ganberako airearen abiaduraren - hots, olatuaren altuera eta periodoaren - arabera aldatzen da. Gainera, turbinaren biraketa abiaduraren arabera sistema desiratutako eremutik galeradun guneetara igaro daiteke. Agerian geratu denez, eremuen arteko mugak ere olatuaren ezaugarriaren arabera aldatzen dira. Honek (2) ekuazioan azaldutakoa berresten du, hau da, kontuan izan beharko dela ganberako airearen abiadura eta turbinaren biraketa abiaduraren arteko erlazioa.

Orain arte egin diren olatu-neurketek adierazten dute bai altuerak eta baita periodoak ere aldaketak jasaten dituztela. Aldaketa nabarienak urtesasoiaren arabera gertatzen diren arren, olatu batetik hurrengora ere desberdintasunak nabari daitezke. Honek kontrol fidagarri eta moldakor baten beharra erakusten du.

Orain arte garatu diren kontrol-algoritmo gehienen [14, 18-20] helburua stalling- edo galera-efektua saihestea izan da. Hala ere, turbinaren abiadura kontrolatuta [21-22] efektu hau saihesteaz gain posible da sistema modu eraginkorragoan ere kudeatzea. Jarraian emango dira bi kontrol mota hauen xehetasunak.

\subsection{Balbularen kontrola}

Esan bezala, gaur egun aire-balbulak erabiltzen dira ur-zutabe oszilatzailean oinarritutako energia zentraletan. Balbula hauek gehiegizko indar mekaniko baten aurrean sorgailua babesteko erabiltzen dira batetik, eta stalling portaera ekiditeko bestetik. Stalling portaeraren ondorioz turbinak sorgailuari emandako potentzia mekanikoa nabarmen murrizten da. Hau dela eta, sorgailuak eman dezakeen potentzia elektrikoa mugatua da, eta beraz, efizientzia urriak lortzen dira.

9. irudiak erakusten du turbina galera-eremuan dagoenean potentzia mekanikoa nabarmen murrizten dela. Hau dela eta, sorgailuari emandako batez besteko potentzia askoz txikiagoa da funtzionamendu normalarena baino. Aurreko atalean esan bezala, momentu-koefizientea dela eta, fluxu-koefizienteak 0.3 balioa gainditzen duenean stalling portaera azaltzen da. (2) ekuazioan ikus daiteke aire-balbulak harrapaketa-ganberako airearen abiadura mugatzen duela fluxu-koefizientea muturreko balio honen azpitik mantentzeko. 
10. irudian aire-balbularen bidezko kontrola erabili da. Ikus daitekeenez, aire-balbularen bidez turbinak emaniko batez besteko potentzia mekanikoa nabarmen hobetu daiteke.

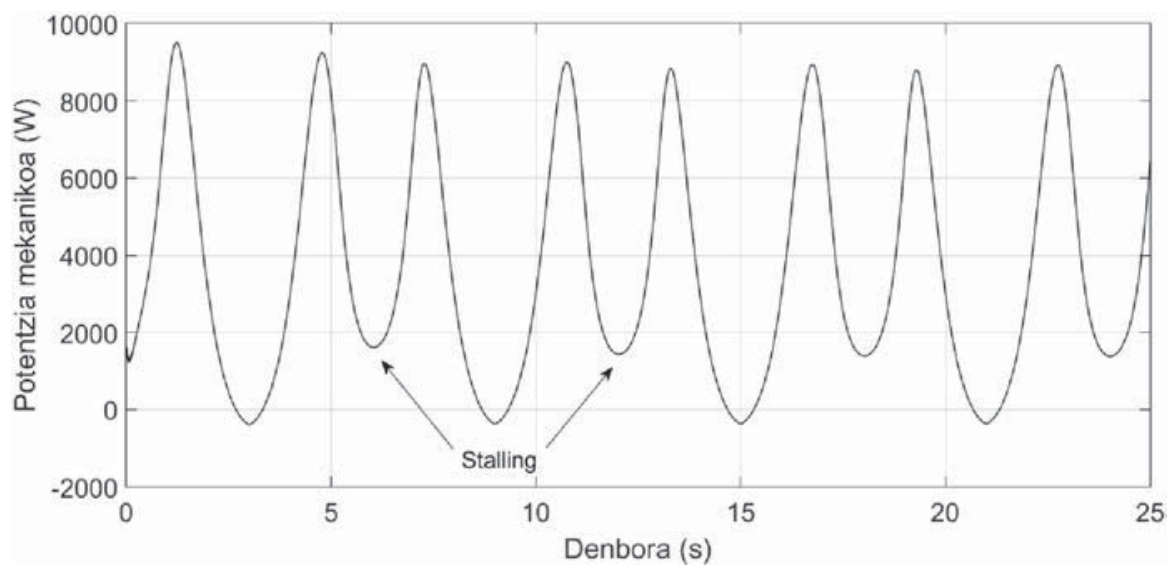

9. irudia. Stalling portaeraren ondorioz lortutako potentzia mekanikoa.

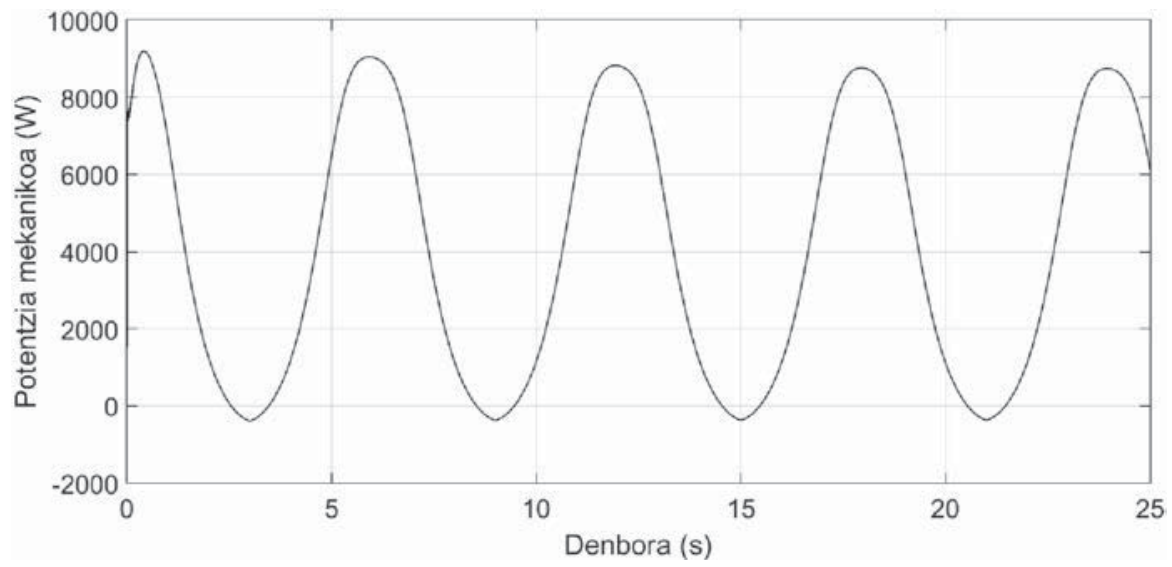

10. irudia. Balbularen kontrolaren bidez lortutako potentzia mekanikoa.

Ur-zutabe oszilatzaileetan erabiltzen diren aire-balbulak tximeleta formakoak dira, 11. irudian ikus daitekeen bezala. Olatuaren arabera balbula honen kokapena erregulatzeko motor bat izaten dute albo batean. Gainera, grabitate indarraz baliatutako emergentziazko itxiera baterako pisua ere ezartzen da. Zentrala deskonektatu behar bada, pisua lurrerantz erortzen da eta balbula guztiz ixten da. 
Jon Lekube Garagarza, Aitor J. Garrido Hernandez, Izaskun Garrido Hernandez
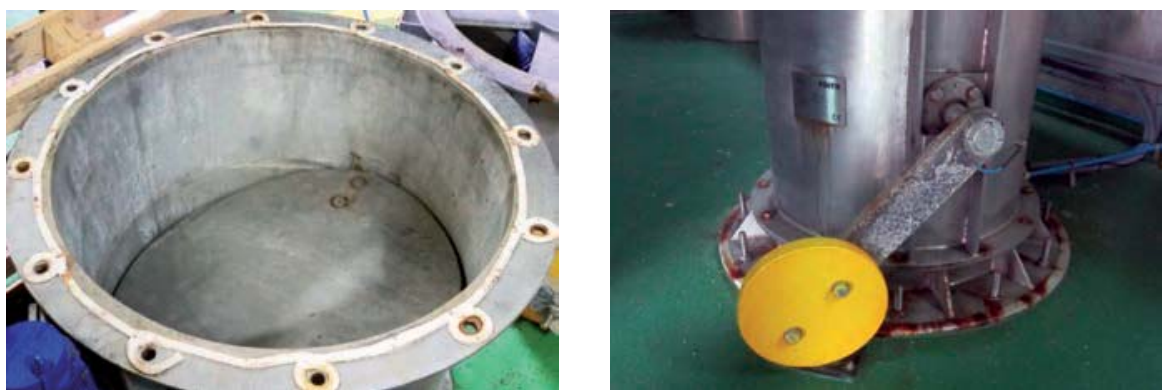

11. irudia. Aire-balbula eta emergentziazko itxierarako pisua.

\subsection{Abiadura-kontrola}

Aireari balbula bidez oztopoa jartzeak potentziaren zati bat alferrik galtzea dakar. Gainera, sistema mekanikoak denbora faktore bati lotuta egon ohi dira beti, denbora behar izaten baitute beraien kokapena erdiesteko. Horretaz gain, elementu hauek inguru kaltegarrietan kokatuta daude itsasoko urak duen kresalaren ondorioz.

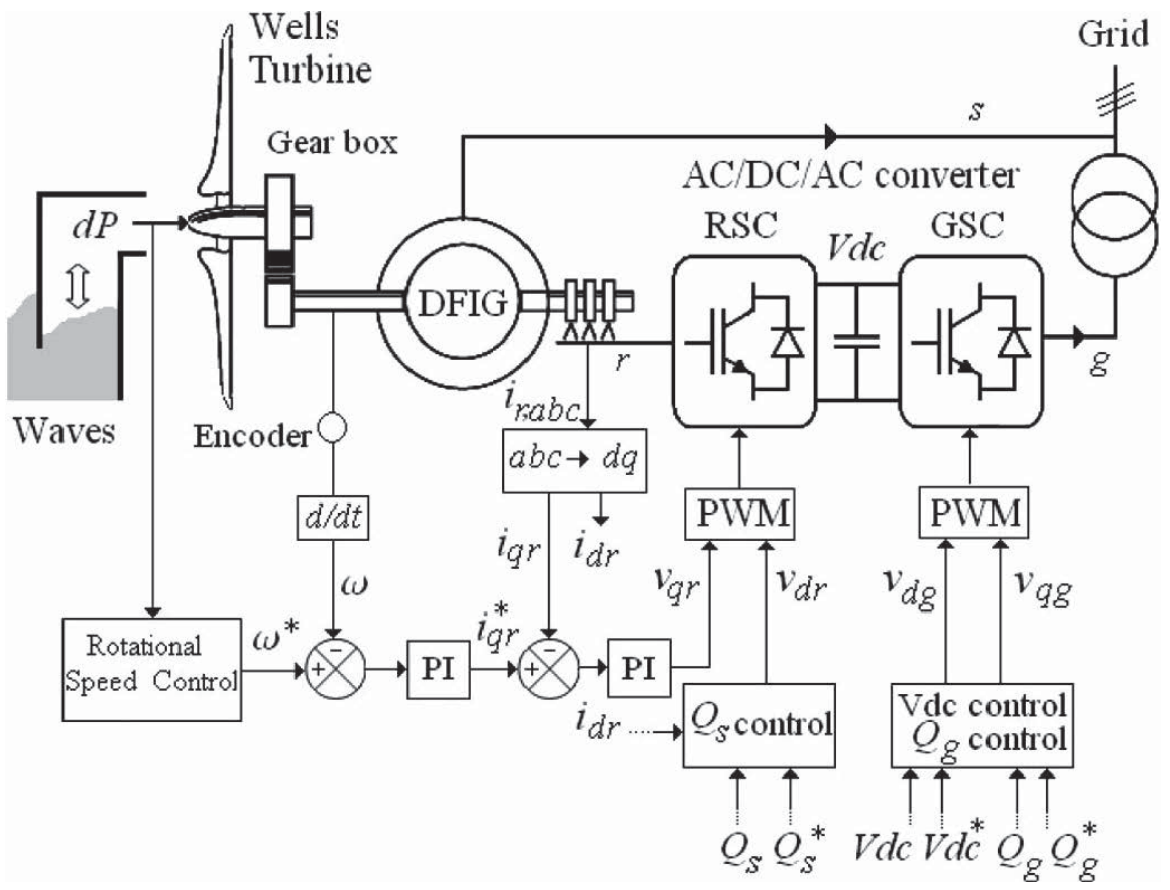

12. irudia. Abiadura-kontrolaren eskema orokorra. 
Bestalde, Mutrikuko olatuen zentralean dauden sorgailuen ezaugarriak medio [23], beharrezkoa da sortzen den potentzia guztia sarera bota aurretik korronte zuzenera helaraztea. Hau dela eta, agerikoa da beharrezkoa dela sorgailuen potentziaren adinako potentzia-bihurgailu bat; hau arazo handi bat litzateke potentzia handiko zentralen kasurako.

Arazo hauek ekidite aldera proposatu da energia eolikoan jada egokiro darabilten baina Mutrikun inplementaturik ez dagoen abiadura kontrola. Horrela, errotorearen, hots turbinaren biraketa-abiadura kontrolatzen da 12. irudian azaltzen den kontrol-eskema erabilita. Horretarako, beharrezkoa da errotoreko korrontea kontrolatzea elikadura bikoitzeko indukzio-makina baten bidez (ingelesez, Doubly-Fed Induction Generator-DFIG). Errotorea bihurgailu baten bidez konektatzen den bitartean, estatorea zuzenean lotzen da sarera. Hau dela eta, bihurgailuak potentzia osoaren \% 25-\% 30a baizik ez du maneiatzen.

8. irudian ikus daiteke turbinak bere abiaduraren arabera aldatu egiten duela sorgailuari ematen dion potentzia mekanikoa. Horrela, badago turbinak potentzia maximoa ematen duen abiadura optimo bat.

Biraketa-abiadura eta potentzia mekanikoaren arteko erlazioak potentzia maximoko puntua zehazten du. 8. irudian lerro etenez adierazi da puntu hori. Horrenbestez, abiadura-kontrolak sorgailuaren errotoreko korrontea finkatzea du helburu. Behin korrontea finkatuta, abiadura optimoa lortzen da aldiune bakoitzean sarrerako olatuaren ezaugarrien arabera.

Gainera, potentzia maximoko puntua jarraituz gero stalling portaera ekiditeko beharrezkoa den gutxieneko abiadura ere lortzen da. Beraz, abiadura-kontrolaren bidez potentzia maximoa lortzeaz gain, stalling portaera ere saihestuko litzateke.

\section{ONDORIOAK}

Artikulu honetan OWC moduan oinarritutako olatuen zentral bat aztertu eta bere errendimendua hobetu asmoz beste kontrol eskema bat proposatu da. Horretarako, potentzia maximoko puntuaren jarraipena egin da sarera entregatutako potentzia handiagotzeko helburuarekin. Erreferentzia modura Mutrikuko NEREIDA MOWC olatuen zentrala erabili da. Kontrol hau garatzeaz gain aire-balbularen funtzionamendua ere azaldu da. Abiadura-kontrolaren kasuan, sistemak sorgailuaren irristaketan eragiten du, bere abiadura sarrerako olatuaren arabera doitzeko. Era horretan, sorgailuak abiadura optimoa erdiesten du sarrerako olatu bakoitzerako. Estrategia honen erabilerak stalling portaera ekiditea ahalbidetzen duen arren, olatu handiko uneetan ezinbestekoa izango da aire-balbularen bidez turbinatik igarotzen den airea erregulatzea. Lortzen da bi kontrol-estrategiek sortu- 
tako potentzia elektrikoa areagotzea, baina potentzia maximoko puntuaren jarraipenean oinarritutako kontrolak efizientzia eta zehaztasun hobea eskaintzen du.

\section{BIBLIOGRAFIA}

[1] «Adoption of the Paris agreement, Draft decision-/CP.21», Framework convention on climate change, 12 December 2015, https://unfccc.int/resource/ docs/2015/cop21/eng/109r01.pdf, azkenengo sarrera 2016ko maiatzaren 26an.

[2] GARRIDO, A.J., GARRIDO, I., BARAMBONES, O., ALKORTA, P. eta MASEDA, F.J. 2008. «Simple linear models for plasma control in tokamak reactors». Proceedings of the International Conference on Control, Automation and Systems (ICCAS '08), 2429-2432.

[3] PAREDES-SÁNCHEZ, J.P., GUTIÉRREZ-TRASHORRAS, A.J., GONZÁLEZ-CABALLÍN, J. M. 2013. «Bio-smartcity: Biomass supply to a Smartcity. A case study». 2013 International Conference on New Concepts in Smart Cities: Fostering Public and Private Alliances (SmartMILE), 1-4.

[4] CASELLA, F. 2004. «Modeling, Simulation, control, and optimization of a geothermal power plant». IEEE Transactions on Energy Conversion, 19, 170-178.

[5] BOAKE, C.B., WHITTAKER, T.J.T. eta FOLLEY, M. 2002. «Overview and Initial Operational Experience of the LIMPET Wave Energy Plant». Proceedings of The Twelfth (2002) International Offshore and Polar Engineering Conference, 586-594.

[6] BEIRAO, P., VALERIO, D. eta SA DA COSTA, J. 2007. «Comparison of control strategies applied to the Archimedes Wave Swing». Proceedings of the European Control Conference 2007, 4651-4658.

[7] WEINSTEIN, A., FREDRIKSON, G., CLAESON, L., FORSBERG, J., PARKS, M.J., NIELSEN, K., JENSES, M.S., ZANDIYEH, K., FRIGAARD, P., KRAMER, M. eta ANDERSEN, T.L. 2003. «AquaBuOYthe offshore wave energy converter numerical modeling and optimization». OCEANS 2003. Proceedings, 4, 1988-1995.

[8] AHMED, T., NISHIDA, K., NAKAOKA, M. 2010. «Grid power integration technologies for offshore ocean wave energy». 2010 IEEE Energy Conversion Congress and Exposition, 2378-2385.

[9] MÜLlER, N., KOURO, S., GLARÍA, J. eta MALINOWSKI, M. 2013. «Medium-voltage power converter interface for Wave Dragon wave energy conversion system». 2013 IEEE Energy Conversion Congress and Exposition, 352-358.

[10] «Annual Report: Ocean Energy Systems (OES) 2015». The Executive Committee of Ocean Energy Systems. https://report2015.ocean-energy-systems. org/, azkenengo sarrera 2016ko maiatzaren 26an. 
[11] ULAZIA, A. eta IBARRA, G. 2015. «Itsas energia irakasten R-rekin». Ekaia, 28, 27-37.

[12] TORRE-ENCISO, Y. 2009. «Mutriku Wave Power Plant: From Conception to Reality». European Federation of Agencies and Regions for Energy and the Environment (FEDARENE).

[13] «Datos históricos: oleaje». Puertos del estado, Ministerio de Fomento. http:// www.puertos.es/es-es/oceanografia/Paginas/portus.aspx, azkenengo sarrera 2016ko maiatzaren 26an.

[14] ALBERDI, M. 2011. «Itsas olatuen energia eraldatzeko zentral baten deskribapena». Ekaia, 24, 237-256.

[15] CHADWICK, A., MORFETT, J. eta BORTHWICK, M. 2004. «Hydraulics in Civil and Environmental Engineering». Spon Press.

[16] LE ROUX, J.P. 2008. «An extension of the Airy theory for linear waves into shallow water». Coastal Engineering, 55, 295-301.

[17] GARRIDO, A.J., OTAOLA, E., GARRIDO, I., LEKUBE, J., MASEDA, F.J., LIRIA, P. eta MADER, J. 2015. «Mathematical Modeling of Oscillating Water Columns Wave-Structure Interaction in Ocean Energy Plants». Mathematical Problems in Engineering, 2015.

[18] GARRIDO, A.J., GARRIDO, I., ALBERDI, M., AMUNDARAIN, M., BARAMBONES, O. eta ROMERO, J. A. 2013. «Robust control of oscillating water column (OWC) devices: power generation improvement». Proceedings of the OCEANS-San Diego, 1-4.

[19] AMUNDARAIN, M., ALBERDI, M., GARRIDO, A.J. eta GARRIDO, I. 2011. «Modeling and simulation of wave energy generation plants: output power control». IEEE Transactions on Industrial Electronics. 58, 105-117.

[20] FALCAO, A.F.D.O., VIEIRA, L.C., JUSTINO, P.A.P. eta ANDRÉ, J.M.C. S. 2003. «By-pass air-valve control of an OWC wave power plant». Journal of Offshore Mechanics and Arctic Engineering, 125, 205-210.

[21] FALCAO, A.F.D.O. 2002. "Control of an oscillating-water-column wave power plant for maximum energy production». Applied Ocean Research, 24, 73-82.

[22] AMON, A., BREKKEN, K.A. eta SCHACHER, A. 2012. «Maximum Power Point Tracking for Ocean Wave Energy Conversion». IEEE Transactions on Industry Applications, 48, 1079-1086.

[23] OSA, J.L. eta ITURREGI, A. 2010. «Selection of the Electrical Generator for a Wave Energy Converter». International Conference on Renewable Energies and Power Quality (ICREPQ'10). 